the auroral display, the extremely singular phenomenon which ha: been described by several of your correspondents. It looked exactly like a white cloud, about $20^{\circ}$ long and $2^{\circ}$ wide, tapered somewhat from the middle to each end ; but it was more luminous than a cloud could well have been at that time. When first seen, its nearest end may have been $30^{\circ}$ east of the moon. Its length was nearly parallel to the horizon, and continued so till lost sight of about as much to the west of the moon; and its passage over an area of some $80^{\circ}$ occupied probably less than a minute. It passed very near to the moon, but I cannot say whether over it or not.

Toppesfield Rectory, Halstead, Essex, Nov. 25

Following up my last week's letter concerning the electric meteoroid, if one may so term it, of the I 7 th inst., I have sifted all the testimony within my knowledge, assigning a numerical weight to each report from internal evidence of its probable value, and correcting for latitude where the altitude of the moon was made the standard of comparison. With data so precarious, and triangles so ill-conditioned, the results can of course only be regarded as a very rough approximation to the truth; for what they are worth, however, they are as follows:-I. That the course of the meteoroid was about S. $70^{\circ} \mathrm{W}$. Probably it was $71^{\circ} 45^{\prime}$, the complement of the magnetic declination. 2. That there was a proper motion of a little more than a mile a minute. 3. That the path was vertically over a line upon the earth's surface, whose least distance from Greenwich was 72 miles. 4 That the actual elevation was 44 miles. On this reckoning the body would seem to have crosied in the zenith in North Belgium, the Boulogne district, Cherbourg, and the north coasts of Brittany.

STEPHEN H. SAXBY

East Clevedon Vicarage, Somerset, November 28

My observation at Ramsbury, near Hungerford, was to the effect that while watching the northern aurora, my attention was called, at ten minutes past six, to this monster meteor, then slowly approaching in a direct line to the moon, which was shining most brilliantiy. It seemed to pass exactly over the disc, and reappeared on the side, much reduced in size, as if going away from us; and at a distance of about $6^{\circ}$ from the moon, scarcely seemed to measure more than $5^{\circ}$ in length, it being then about $6 \mathrm{~h} .8 \mathrm{~m}$., which corresponds with the position over Sidmouth at that time. It was very definite In form, like a torpedo. I estimated its length at $15^{\circ}$, and $3^{\circ}$ in breadth. I hope to have a hand-made photograph of its appearance ready for publication, by the Autotype Company, in a few days, and on the same sheet is a hand-delineation of the great comet to the same scale.

The Rookery, Ramsbury

\section{Lavoisier, Priestley, and the Discovery of Oxygen}

In the last number of this journal my friend Mr. Tomlinson has criticised my observations on the respective claims of Lavoisier and Priestley to the discovery of oxygen. Without examining, or attempting to refute one of my arguments, and without the citation of any warrant, or authority, he has stated his opinions with an asseveration worthy of a $15^{\text {th }}$ century Professor of Dogmatic Theology, His letter consists of five general statements, and nine dogmatic assertions. I have endeavoured to show that of the former, two are self-evident truths, or at least universally-admitted conclusions, while the remaining three are misstatements; and that of the latter five are completely erroneous, 'while three are open to question, and one is correct.

I. The universally admitted conclusions are $:-(a)$ that "chemistry has no nationality," and that "discoverers are mutually dependent." Nothing that I have said can possibly be construed into the expression of a shadow of doubt concerning the truth of either of these statements.

2. The three misstatements are that $(a)$ I have "thought it necessary to revive the old oxygen quarrel," (b) that I have "taken an unpatriotic part against Priestley," and $(c)$ " endorsed the complacent statement of Wurtz, that chemistry is a French science founded by Lavoisier." If it be reviving a quarrel and acting an unpatriotic part against a man, to show that by the light of evidence hitherto overlooked one of the greatest scientific men of the last century has been unfairly accused of dishonesty, I am quite willing to be considered unpatriotic and a quarrel-monger. As to endorsing the statement of M. Wurtz, all I say is that he did not say it "without reason." Many people regard the assertion as quite unreas onable. I confess I Go not, but at the same time I do not mean to say that $I$ fully accept it.

[As to my "forgetting, perhaps, that the title "La Chimie Française' was invented by Fourcroy, and objected to by Lavoisier," I may say that I do not see that this bears the least upon the question. Lavoisier's own words are "Cette théorie n'est donc pas, comme je l'entends dire la théorie des chimistes français, elle est la mienne, et c'est une propriété que je réclame auprès de mes contemporains et de la postérité." (Euvres de Lavoisier, tome 2. I862, p. 104.) Dr. Thomas Thomson (Hist. of Chem. p. ror, vol. ii.) says, "Lavoisier's objection, then, to the phrase La Chimie Francaise, is not without reason, the term Lavoisierian Chemistry should undoubtedly be substituted for it." But this does not affect the question whether or no chemistry is a French science as M. Wurtz puts it, for surely Lavoisier was a Frenchman of the French. I say nothing, however, as to the justification of the remark that chemistry is a French science.]

3. "That the compound is always equal to the sum of its elements was known long before Lavoisier" remarks Mr. Tomlinson. I have nowhere asserted that it was not, but the statement is new to me, and I should like to have references.

4. ... "So early as 1630 Rey gave the true explanation of the increase of the weight of metals by calcination." Any one who will take the trouble to read through Rey's essay "sur la recherche de la cause pour laquelle lestain et le plomb augmentent de poids quand on les calcine," cannot fail to observe how very vague his ideas on the subject were. He indeed attributed the increase of weight to thickened air (l'air espessi), but the following, as I have elsewhere stated, seems to have been his mode of reasoning:-Air possesses weight; it may be produced by heating water, which during distillation separates into a heavier and a lighter part; hence as air approximates to a liquid nature, it may be supposed to be separated into a heavier and a lighter part by the action of heat ; now the heavier part (the "dregs") of air is more nearly allied to a liquid than air, for it has assumed a "viscid grossness," and this part attaches itself to calces during the process of calcination, and causes such of them as possess much ash to be heavier than before calcination. If we calcine a vegetable or animal substance there is no gain of weight, because the assimilated thickened air weighs less than the volatile matter expelled by heat; but in the case of a metal the assimilated air weighs more than the volatile matter expelled, hence there is a gain of weight. Thus he imagined that all calces, from a vegetable ash to a metallic calx, attract this thickened air. It can scarcely be said that a man with these extremely crude notions "gave the true explanation of the increase of weight of metals by calcination."

5 and 6. "Lavoisier's note of 1772 was, as he admitted, based upon Priestley's earlier experiments, begun in I744." I can nowhere find in Lavoisier's writings any admission of the kind alluded to. (Will Mr. Tomlinson give references ?). On the other hand, I do find a note by Lavoisier at the end of Chap. VI. De la calcination des metaux, published in the Opuscules Physiques et Chimiques (1774), (Euvres, Vol, I., p. 62I), in which he says, "Je n'avais point connaissance des experiences de M. Priestley, lorsque je me suis occupè de celles rapportées dans ce chapitre. Il a observé, comme moi et avant moi, . . . \&c., \&c." This would seem to sufficiently disprove the former statement.

Mr. Tomlinson speaks of Priestley's "earlier experiments begun in I 744." Now Priestley was born in I 733, and although no doubt a clever fellow he certainly did not begin to experiment at eleven years of age! His first paper on gases was pub. lished thirty-nine years later, viz. in 1772 .

7. That "the acceptance of Lavoisier's doctrine was mainly due to the capital discovery of the composition of water by Cavendish in I 784," I utterly deny ; and if desirable will shou cause why. Nevertheless, as it has been so asserted, we may, for the present at least, regard it as an open question.

8. Mr. Tomlinson calls Black, Priestley, and Cavendish, "the founders of pneumatic chemistry." Surely John Mayor and Stephen Hales have a better right to the title.

9. "Priestley discovered oxygen in I774." This, no doubt, is true in a sense because everybody says so. If it means that he got a gas from red oxide of mercury it is true. But let us not forget:- $(a)$ that he discovered it by a random experiment, "by 